\title{
Electrosprayed chitosan nanoparticles: facile and efficient approach for bacterial transformation
}

\author{
Morteza Abyadeh ${ }^{1} \cdot$ Esmaeil Sadroddiny $^{2} \cdot$ Ammar Ebrahimi $^{3} \cdot$ Fariba Esmaeili $^{1} \cdot$ Farzaneh Saeedi Landi $^{1}$. \\ Amir Amani ${ }^{1,4}$
}

Received: 17 May 2017 / Accepted: 3 December 2017 / Published online: 28 December 2017

(c) The Author(s) 2017. This article is an open access publication

\begin{abstract}
A rapid and efficient procedure for DNA transformation is a key prerequisite for successful cloning and genomic studies. While there are efforts to develop a facile method, so far obtained efficiencies for alternative methods have been unsatisfactory (i.e. $10^{5}-10^{6} \mathrm{CFU} / \mu \mathrm{g}$ plasmid) compared with conventional method (up to $10^{8} \mathrm{CFU} / \mu \mathrm{g}$ plasmid). In this work, for the first time, we prepared chitosan/pDNA nanoparticles by electrospraying methods to improve transformation process. Electrospray method was used for chitosan/pDNA nanoparticles production to investigate the non-competent bacterial transformation efficiency; besides, the effect of chitosan molecular weight, N/P ratio and nanoparticle size on non-competent bacterial transformation efficiency was evaluated too. The results showed that transformation efficiency increased with decreasing the molecular weight, N/P ratio and nanoparticles size. In addition, transformation efficiency of $1.7 \times 10^{8} \mathrm{CFU} / \mu \mathrm{g}$ plasmid was obtained with chitosan molecular weight, N/P ratio and nanoparticles size values of $30 \mathrm{kDa}, 1$ and $125 \mathrm{~nm}$. Chitosan/ pDNA electrosprayed nanoparticles were produced and the effect of molecular weight, N/P and size of nanoparticles on transformation efficiency was evaluated. In total, we present a facile and rapid method for bacterial transformation, which has comparable efficiency with the common method.
\end{abstract}

Keywords Transformation $\cdot$ Chitosan $\cdot$ pDNA $\cdot$ Nanoparticles $\cdot$ Electrospray

\section{Introduction}

Bacterial transformation is a process by which exogenous DNA is introduced into a cell. This process is an important step in DNA cloning, which is a fundamental component in recombinant DNA technology and some medical researches. Common methods for transforming bacterial cells with

Amir Amani

aamani@sina.tums.ac.ir

1 Department of Medical Nanotechnology, School of Advanced Technologies in Medicine, Tehran University of Medical Sciences, Tehran, Iran

2 Department of Medical Biotechnology, School of Advanced Technologies in Medicine, Tehran University of Medical Sciences, Tehran, Iran

3 Department of Medical Biotechnology, School of Paramedicine, Guilan University of Medical Sciences, Rasht, Iran

4 Medical Biomaterials Research Center, Tehran University of Medical Sciences, Tehran, Iran exogenous DNA are chemo-transformation (mostly, treatment with $\mathrm{CaCl}_{2}$ ) [1] and electroporation [2]. Other transformation methods such as laser irradiation [3], sonoporation [4], biolistic transformations [5] may also be observed in the literature. Nevertheless, these methods are complicated, expensive and damaging to cells. They also require a step of preparing competent cells which is a time consuming process $[6,7]$. Therefore, providing a simple and efficient method for DNA transformation appears to be necessary.

The electrospray process, also called electrohydrodynamic atomization (EHDA), is a technique based on the application of high voltage to a metal nozzle to break a liquid which is leaving the nozzle into smaller droplets. The small droplets then fly towards a collector which is connected to earth or counter electrode [8]. Electrospray is an attractive, cost-effective and simple method for producing nano- and micro-particles that are used for drug delivery and other pharmaceutical purposes [9]. The method takes the benefits of mild conditions that are suitable for sensitive therapeutic agents like DNA [9]. Reviewing the literature, very limited reports are found about using electrospray for 
DNA delivery into mammalian [7] and bacterial cells [6, 7]. Yusuke Okubo et al. used electrospray to spray droplets into bacterial culture to make a mild damage on the cell surface to increase penetration of plasmid to bacteria. Their findings indicated that transformation efficiency was $10^{4}-10^{5}$ cells/ $\mu \mathrm{g}$ plasmid [7]. In another study, electrosprayed solution of plasmid containing gold nanoparticles (Au NPs) which were directed against bacterial cells increased transformation efficiency up to $10^{6} \mathrm{CFU} / \mu \mathrm{g}$ plasmid [6].

Chitosan as a polymeric carrier has received great deal of attention for delivery of biomaterials into cells, especially for gene delivery into mammalian cells $[10,11]$. The polycationic polymer is an attractive gene carrier with high efficacy of gene transfer and relatively high loading capacity [12]. Previous studies have shown ability of chitosan to mediate opening of tight junctions for delivery purposes [13]. Researchers have also stated that interactions between chitosan and cell membrane may lead to denaturing membrane proteins and increase permeability of cell membrane [14].

The only works that we found on the application of electrospray for bacterial transformation showed substantially lower transformation efficiency compared with that of conventional methods such as heat shock and electroporation $[6,7]$. Here in, we tried to improve delivery of PUC19 as a model gene, using electrosprayed chitosan nanoparticles by optimizing some formulation parameters to develop a rapid and yet efficient method for transformation purposes.

\section{Materials and methods}

Chitosan with different molecular weights $(7,30,100,500 \mathrm{kDa})$ and $72 \%$ degree of deacetylation was purchased from Zhengzhou Sigma Chemical Co. (China). PUC19 vector (2686) was obtained from Iranian biological resource center (Iran). All other chemicals/reagents were purchased from Sigma-Aldrich (USA).

\section{Preparation of chitosan/plasmid polyplex}

Stock solutions of chitosan with different molecular weights were prepared with dissolving in $25 \mathrm{mM}$ sodium acetate buffer (pH: 5.5) using ultrasound. Solutions were then diluted to obtain N/P ratios of $0.25-5.0$ and filtered through $0.2 \mu \mathrm{m}$ filters. Subsequently, $10 \mu \mathrm{l}$ of PUC19 plasmid ( $5 \mathrm{ng} / \mu \mathrm{l})$ was added to $90 \mu$ of the diluted chitosan solutions. Total volume was then adjusted to $0.25 \mathrm{ml}$ using deionized sterile water.

\section{Apparatus design and experimental setup}

Syringe was supplied with a programmable pump. Solution of CS/pDNA was pumped through $1 \mathrm{ml}$ plastic syringe with blunt-ended 30-gauge stainless steel needle. A stable positive high voltage supplier was connected to nuzzle tip. A petri dish containing Escherichia coli was adjusted on grounded aluminum dish, $3 \mathrm{~cm}$ below the nozzle tip and the solution was electrosprayed with constant flow rate of $1 \mathrm{ml} / \mathrm{h}$ directly into the petri dish for transformation studies.

All devices before experiment were placed into a biosafety chamber and were treated using $70 \%$ Ethanol and UV irradiation for $30 \mathrm{~min}$.

\section{Size of nanoparticles measurement}

Dynamic laser light scattering technique (Nano-Zetasizer, Malvern) equipped with the Malvern PCS software (version 1.27) was used to measure the size of the chitosan and chitosan/pDNA nanoparticles after electrospray without any dilution. Morphology of CS/pDNA nanoparticles was examined by transmission electron microscopy (TEM, Zeiss-EM10C-100 kV, Germany).

DNA concentration was determined using a Nano Drop ND-1000 Spectrophotometer (Nano-Drop Technologies, USA) and agarose gel electrophoresis.

\section{Bacterial cultivation}

Noncompetent E. coli (K12 strain) solution was spread on a $1.5 \%$ agar Luria-Bertani (LB) dish and incubated overnight at $37^{\circ} \mathrm{C}$. The plasmid/chitosan in sodium acetate buffer $(25 \mathrm{mM}$, $\mathrm{pH}:$ 5.5) was electrosprayed at constant voltage and flow rate of $10 \mathrm{kV}$ and $1 \mathrm{ml} / \mathrm{h}$, respectively, on the cultured bacterial dish for $15 \mathrm{~min}$. Then, bacterial layer on the surface of each dish was inoculated in $1 \mathrm{ml}$ of LB medium and shaken at $200 \mathrm{rpm}\left(37^{\circ} \mathrm{C}\right)$ for $5 \mathrm{~h}$ to recover cell growth. Then, to select the transformants, cultured bacterial LB mediums were spread on $1.5 \% \mathrm{LB}$ agar dish containing ampicillin $(100 \mu \mathrm{g} / \mathrm{ml})$ and incubated overnight. Apparent colonies on the antibiotic bearing culture medium, represent bacterial cells that contain the transformed plasmid, thus, were counted.

\section{Confirmation of plasmid delivery to $E$. coli}

Subsequent to transformation process and selecting transformants (as single colonies on LB broth containing ampicillin, as an antibiotic resistance marker), the plasmid was extracted from transformants $E$. coli and treated with double digesting using BamHI and NdeI to confirm the successful transformation.

\section{Comparison with heat shock transformation method}

Preparation and transformation of competent $E$. coli cells were performed according to a previously described method 
[15]. Briefly, strain grown in LB to an optical density of $0.3-0.4$ at $600 \mathrm{~nm}$ was used to prepare competent cells. Bacterial culture was centrifuged, and heat shock competent cells were prepared by incubating the bacteria in ice-cold $100 \mathrm{mM} \mathrm{CaCl}{ }_{2}$ for $20 \mathrm{~min}$. After centrifugation, cells were resuspended in $100 \mu \mathrm{l}$ of $100 \mathrm{mM} \mathrm{CaCl}_{2}$. All the steps were performed in ice-cold conditions. Plasmid ( $5 \mathrm{ng} / \mu \mathrm{l})$ was added to the competent cells, and heat shock was given at $42{ }^{\circ} \mathrm{C}$ for $90 \mathrm{~s}$. Cells were kept on ice for $2 \mathrm{~min}$, then, shaken at $37{ }^{\circ} \mathrm{C} 200 \mathrm{rpm}$ for $1 \mathrm{~h}$ after addition of fresh LB medium. Then, cultured on LBA overnight and colonies were counted.

\section{Results and discussion}

The most common methods for bacterial transformation are heat shock and electroporation, with advantage of high efficiency (up to $10^{8} \mathrm{CFU} / \mu \mathrm{g}$ plasmid). However, in both

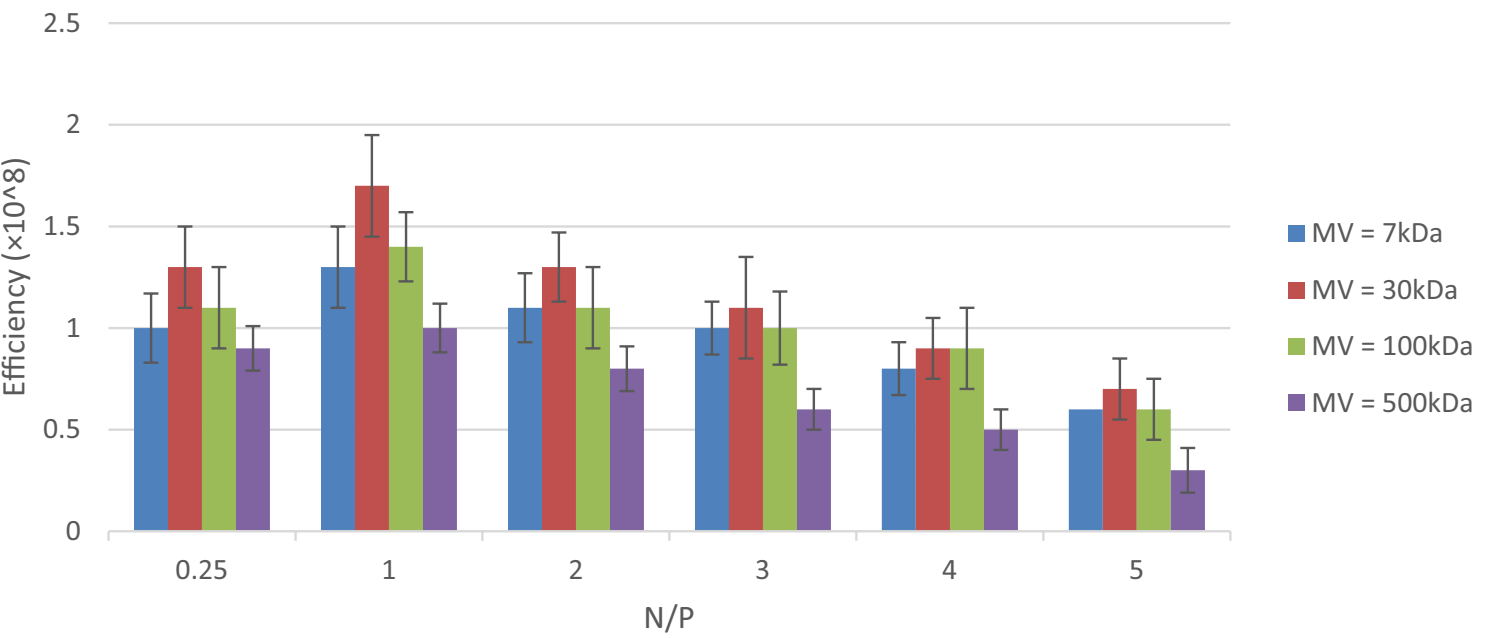

Fig. 1 Effects of the N/P and molecular weight on transformation efficiency (TE)

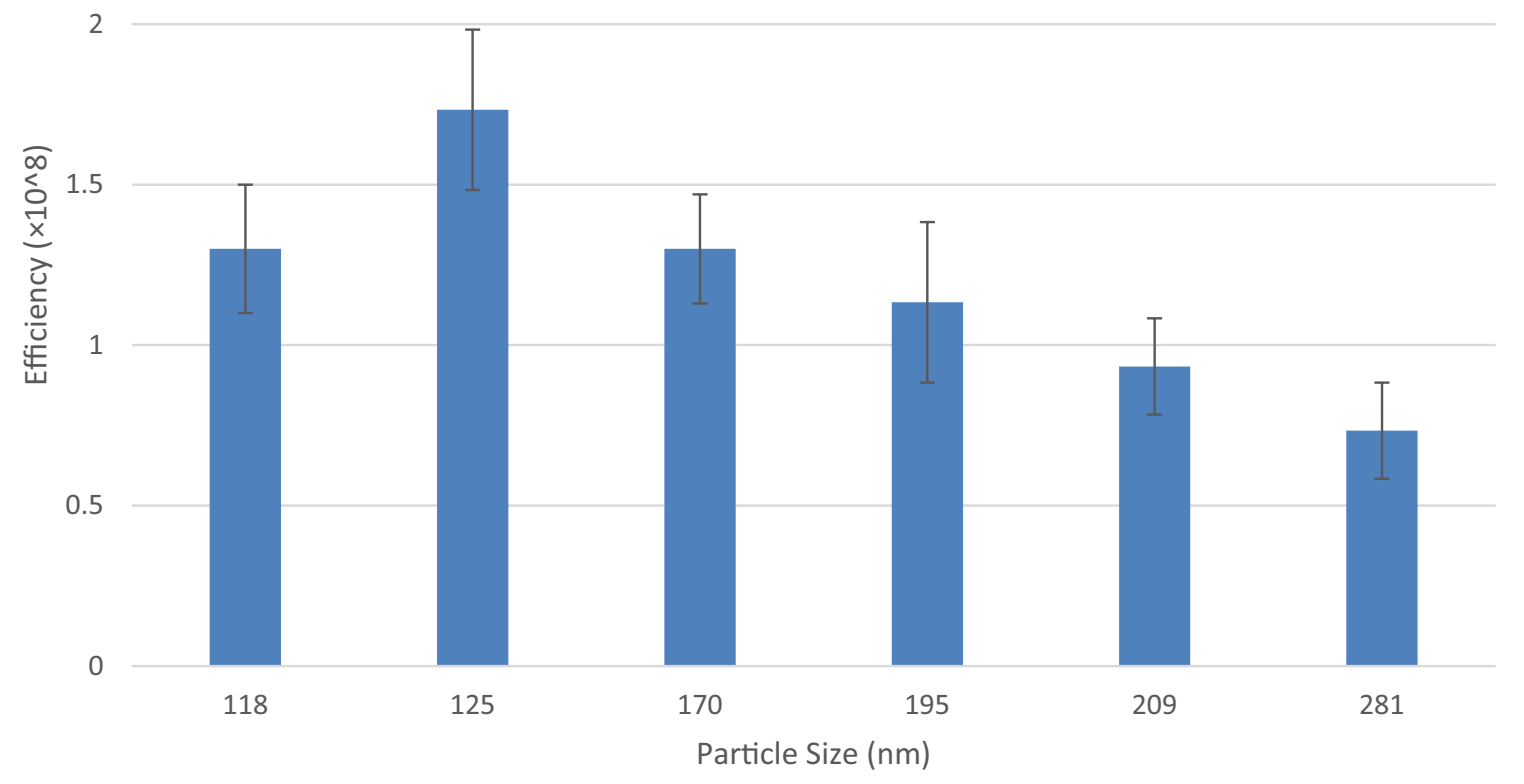

Fig. 2 Effects of the nanoparticles size on transformation efficiency (TE) 


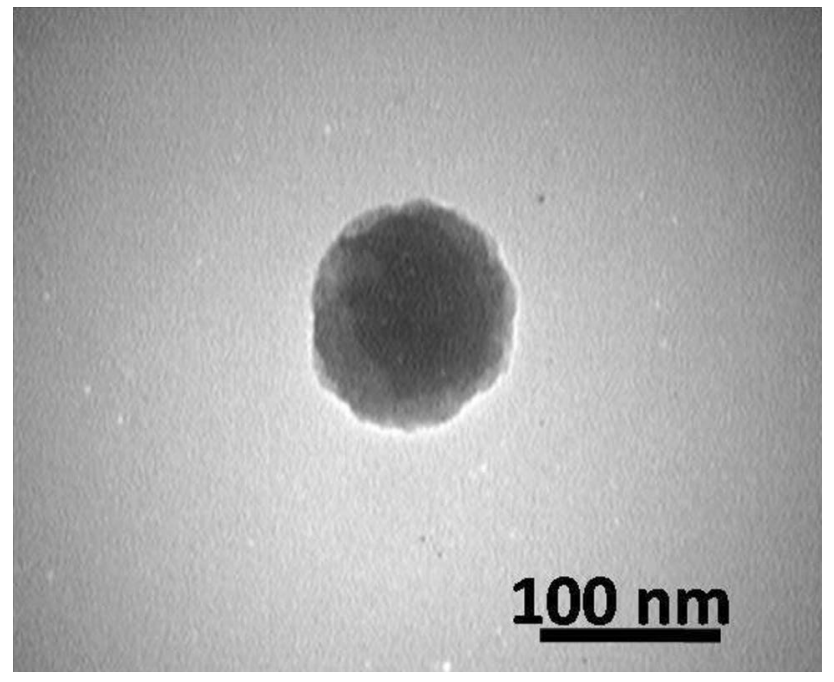

Fig. 3 TEM image of pDNA/chitosan nanoparticles. Chitosan molecular weight, N/P and size of pDNA/Chitosan were $30 \mathrm{kDa}, 1$ and $125 \mathrm{~nm}$, respectively, when applied voltage and flow rate were constant in $10 \mathrm{kV}$ and $1 \mathrm{ml} / \mathrm{h}$

methods, preparation of competent cells is a time consuming process which requires relatively tedious steps [16]. In this study, we used electrosprayed chitosan nanoparticles to develop a rapid and efficient approach compared with common methods. As shown in Fig. 1, increase in molecular weight from 7 to $100 \mathrm{kDa}$ makes no significant change transformation efficiency. However, further increases make a significant decrease in the efficiency. Also, by increasing the N/P ratio, transfection efficiency decreases. Previous reports in transfection of mammalian cells indicate that high MW chitosan and high N/P ratio may form stable chitosan/DNA complexes which reduce release of DNA from the nanoparticles inside the cell, leading to lower transfection efficiency [17]. A second reason for our finding could be increase in antibacterial activity of chitosan nanoparticles as a function of increase in molecular weight [14] and N/P ratio [18]. This causes irreversible damages on cell membrane which may lead to cell death. The effect of size may also be an important phenomenon: Fig. 2 reports the effect of particle size in chitosan samples with similar molecular weight (i.e. $30 \mathrm{kDa}$ ) having different N/P ratios (i.e., different chitosan concentration). From the figure, by increasing N/P, generally, transformation decreases which could be due to increase in size of nanoparticles.

Overall, optimum values of $30 \mathrm{kDa}$ and 1 may be suggested for the molecular weight and N/P to obtain size of $125 \mathrm{~nm}$ for pDNA/chitosan nanoparticles, with highest transformation efficiency (Fig. 3).

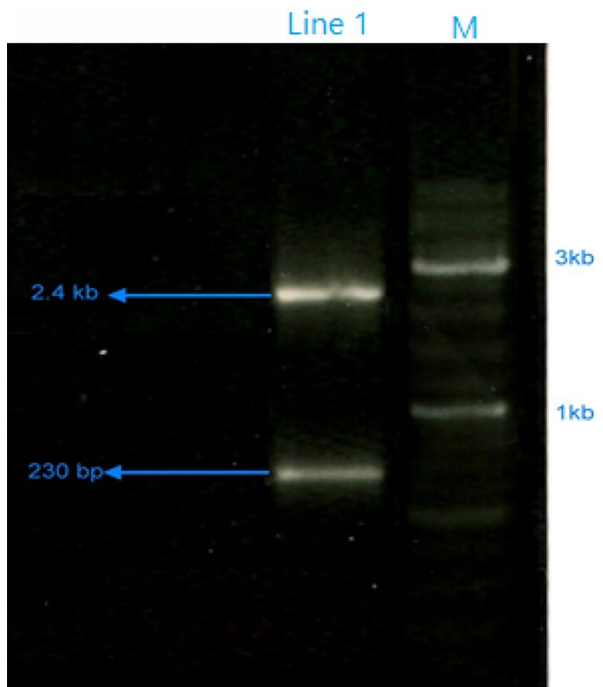

Fig. 4 Confirmation of transformation in E. coli by restriction enzyme analysis. M: Marker, Line1: PUC19 (Total length: 2686 bp) used for transformation and digested with BamHI and NdeI (expected sizes of the band are 234 and $2452 \mathrm{bp}$ )

\section{Transformation confirmation}

Transformation was confirmed by restriction enzyme digestion of transformants bacterial cells extracted plasmid (Fig. 4). As no change in plasmid conformation is observed, a successful delivery of gene along with a mild process is confirmed for electrospray process.

In total, the aim of this study was to present a rapid and effective method for bacterial transformation that is an essential step in recombinant DNA technology. This method is easy and does not require preparation of competent cells, with considerable transformation efficiency achieved $\left(1.7 \times 10^{8} \mathrm{CFU} / \mu \mathrm{g}\right.$ plasmid $)$, compared with commonly used method of heat shock. Effect of chitosan molecular weight, N/P ratio and NPs size on transformation efficiency was investigated and highest transformation efficiency was obtained at $30 \mathrm{kDa}, 1$ and $125 \mathrm{~nm}$ for chitosan molecular weight, N/P ratio and NPs size, respectively.

Acknowledgement This research has been supported by Tehran University of Medical Sciences \& health Services Grant No. 93-01-87-25230.

Open Access This article is distributed under the terms of the Creative Commons Attribution 4.0 International License (http://creativecomm ons.org/licenses/by/4.0/), which permits unrestricted use, distribution, and reproduction in any medium, provided you give appropriate credit to the original author(s) and the source, provide a link to the Creative Commons license, and indicate if changes were made. 


\section{References}

1. Tang, X., Nakata, Y., Li, H.-O., Zhang, M., Gao, H., Fujita, A., Sakatsume, O., Ohta, T., Yokoyama, K.: The optimization of preparations of competent cells for transformation of E. coli. Nucleic Acids Res 22(14), 2857 (1994)

2. Calvin, N., Hanawalt, P.: High-efficiency transformation of bacterial cells by electroporation. J Bacteriol 170(6), 2796-2801 (1988)

3. Tiflova, O., Leonov, P., Karbysheva, E., Shakhnabatian, L.: Effect of He-Ne-laser irradiation on plasmid transformation of Escherichia coli bacteria. Mikrobiologiia 66(5), 640-643 (1996)

4. Song, Y., Hahn, T., Thompson, I.P., Mason, T.J., Preston, G.M., Li, G., Paniwnyk, L., Huang, W.E.: Ultrasound-mediated DNA transfer for bacteria. Nucleic Acids Res. 35(19), e129 (2007)

5. Shark, K.B., Smith, F.D., Harpending, P.R., Rasmussen, J.L., Sanford, J.C.: Biolistic transformation of a procaryote, Bacillus megaterium. Appl Environ Microbiol 57(2), 480-485 (1991)

6. Lee, Y.-H., Wu, B., Zhuang, W.-Q., Chen, D.-R., Tang, Y.J.: Nanoparticles facilitate gene delivery to microorganisms via an electrospray process. J Microbiol Methods 84(2), 228-233 (2011)

7. Okubo, Y., Ikemoto, K., Koike, K., Tsutsui, C., Sakata, I., Takei, O., Adachi, A., Sakai, T.: DNA introduction into living cells by water droplet impact with an electrospray process. Angew Chem Int Ed 47(8), 1429-1431 (2008)

8. Hayati, I., Bailey, A., Tadros, T.F.: Mechanism of stable jet formation in electrohydrodynamic atomization. Nature 319(6048), 41-43 (1986)

9. Bock, N., Dargaville, T.R., Woodruff, M.A.: Electrospraying of polymers with therapeutic molecules: state of the art. Prog Polym Sci 37(11), 1510-1551 (2012)

10. Bowman, K., Leong, K.W.: Chitosan nanoparticles for oral drug and gene delivery. Int J Nanomed 1(2), 117 (2006)
11. Thibault, M., Nimesh, S., Lavertu, M., Buschmann, M.D.: Intracellular trafficking and decondensation kinetics of chitosan-pDNA polyplexes. Mol Ther 18(10), 1787-1795 (2010)

12. Mao, H.-Q., Roy, K., Troung-Le, V.L., Janes, K.A., Lin, K.Y., Wang, Y., August, J.T., Leong, K.W.: Chitosan-DNA nanoparticles as gene carriers: synthesis, characterization and transfection efficiency. J Control Release 70(3), 399-421 (2001)

13. Grenha, A., Grainger, C.I., Dailey, L.A., Seijo, B., Martin, G.P., Remuñán-López, C., Forbes, B.: Chitosan nanoparticles are compatible with respiratory epithelial cells in vitro. Eur J Pharm Sci 31(2), 73-84 (2007)

14. Kong, M., Chen, X.G., Xing, K., Park, H.J.: Antimicrobial properties of chitosan and mode of action: a state of the art review. Int J Food Microbiol 144(1), 51-63 (2010)

15. Chung, C., Niemela, S.L., Miller, R.H.: One-step preparation of competent Escherichia coli: transformation and storage of bacterial cells in the same solution. Proc Natl Acad Sci 86(7), 21722175 (1989)

16. Tan, H., Fu, L., Seno, M.: Optimization of bacterial plasmid transformation using nanomaterials based on the yoshida effect. Int $\mathrm{J}$ Mol Sci 11(12), 4962-4972 (2010)

17. Lavertu, M., Méthot, S., Tran-Khanh, N., Buschmann, M.D.: High efficiency gene transfer using chitosan/DNA nanoparticles with specific combinations of molecular weight and degree of deacetylation. Biomaterials 27(27), 4815-4824 (2006)

18. Qi, L., Xu, Z., Jiang, X., Hu, C., Zou, X.: Preparation and antibacterial activity of chitosan nanoparticles. Carbohyd Res 339(16), 2693-2700 (2004)

Publisher's Note Springer Nature remains neutral with regard to urisdictional claims in published maps and institutional affiliations. 